UDC 519.6

$10.23947 / 2587-8999-2018-2-67-75$

\title{
Development the transport and transportation model of nitrogen, phosphorus and silicon compounds in shallow waters*
}

\author{
A.A. Semenyakina ${ }^{* *}$, V.V. Sumbaev ${ }^{* * *}$, S.V. Protsenko**** \\ Southern Federal University, Taganrog, Russia \\ Supercomputers and Neurocomputers Research Center, Co Ltd., Taganrog, Russia \\ Don State Technical University, Rostov-on-Don, Russia
}

The paper covers stoichiometric ratios of nutrients for phytoplankton algae on the basis of which a limiting substance can be determined. Observational models describing the consumption, accumulation of nutrients by phytoplankton and the growth rate of phytoplankton are considered. Three-dimensional mathematical transformation model of phosphorus, nitrogen and silicon forms in the problem of phytoplankton dynamics for shallow waters is developed and researched. It takes into account the convective and diffusive transports; absorption and isolation of nutrients by phytoplankton; transformation cycles of phosphorus, nitrogen and silicon forms.

Keywords: mathematical model; transformation; biogenic substances; phytoplankton; stoichiometric ratios; biogeochemical cycle.

Introduction. Many papers devoted to the prediction of models of biogeochemical cycles as stochastic systems is appeared in 1980s. For example, paper by Straten и Keesman [1]. Many models were calibrated according to observations by researchers such as Park [2], Bierman [3], Chen [4], Jorgensen [5, 6], etc. use The Michaelis-Menten expression is used in most models for reflection the restriction of individuals' development by nutrients. Three-dimensional-space models of biogeochemical cycles with high resolution are necessary for development hydrobiology models of shallow waters.

Main factors, affecting the consumption rate of nutrients by living organisms, are the intensity of solar radiation and the availability of water nutrients, which are the energy and material bases of activity and growth of organisms. The temperature effects on the reaction rate, occurring in living organisms. Salinity and $\mathrm{pH}$ also have an effect.

Organisms can used specific resource that will help them to compete better with each other or protect themselves from environmental harm or predation at adaptation in the water environment. The Liebig minimum law is used in the case if the organism uses more than one resource for the development [7].

\footnotetext{
* The research is done on theme no. 6905.2017/БЧ within the frame of the government task of the Ministry of Education and Science of the Russian Federation in R\&D.

**E-mail: j.a.s.s.y@mail.ru, valdec4813@mail.ru.

${ }^{* * *}$ E-mail: rab55555@ rambler.ru.
} 
We described nutrients that can limit the development of living organisms in the water environment [8]. Carbon and hydrogen are the main constituents of the atoms of most organic substances. It available for autotrophs in the water environment mainly through the combined $\mathrm{CO}_{2}$ and the water directly. Oxygen is also available in a combined form; it requires for animals and plants in elemental form for respiration. Its presence or absence controls by many reactions between other nutrients in sediments and in some ways in the water. Nitrogen is a significant component of many molecules, amino acids, nucleic acids, etc. Phosphorus has a leading role in the photosynthetic process in the ATP/ADP energy transfer system. Sulfur is a component of amino acids and has an essential role in the anaerobic benthic environment. Iron has an important role as a limiting nutrient in some areas. Silicon is a key element in the development of diatoms, which are characterized by silicon structures (frustules).

The main processes in the cycle of nitrogen transformations are the ammonium, ammonia consumption by phytoplankton, nitrification and denitrification. Ammonium is the conversion process of nitrogen organic forms (especially proteins) to ammonia. Nitrogen is mainly in the form of amino acids, purines and pyrimidines in bottom sediments. They are divided into a series of enzymes in aerobic and anaerobic conditions in carbon dioxide, ammonia or hydrogen sulfide, depending on the presence of oxygen, sulfur, obtained from amino acids.

The ammonification process (or, as it is called, a mineralization or hydrolysis) is taken into account in the construction of many models of hydrobiological processes. It is assumed that there is a certain limit level of nitrogen consumption, which is expressed by the Michaelis-Menten equation, in which the half-saturation constant for inorganic nitrogen and the nitrogen concentration is defined and expressed by the sum of the forms of nitrate and ammonium.

$$
K_{a c t}=K_{\max } \frac{\mathrm{NH}_{4}+\mathrm{NO}_{3}}{\mathrm{NH}_{4}+\mathrm{NO}_{3}+\mathrm{KN}_{1 / 2}},
$$

where $K_{\max }$ is a maximum value of the consumption level; $K_{a c t}$ is the current value of the consumption level; $K N_{1 / 2}$ is a half-saturation coefficient. Note that the current value of the consumption level is equal to half the maximum value of the consumption level if the total concentration of ammonium and nitrate is equal to the half-saturation coefficient.

Nitrification bacteria were considered by Kowalchuk [9]. Chemolithotrophic bacteria convert the ammonia into nitrite ions, which is oxidized to the nitrate mainly by bacteria of the Nitrobacter genus, in aerobic environment. Therefore, the concentration of nitrite is relatively low. Nitrification process includes the changing of a nitrogen ion from positive to negative. It is especially important in bottom sediments where positive ions are attached to clay particles while negative ions move freely in water.

Denitrification is carried out by a group of anaerobic bacteria that can reduce the amount of nitrate by assimilating it. The process does not occur if there is already a lot of ammonium. Some bacteria separate the oxygen from the remaining nitrite, converting it to ammonium ions (the ammonium nitrate process). The sequence of denitrification resulting from the activity of some anaerobic heterotrophs can lead to nitrogen losses due to the formation of gaseous forms. If the concentration of nitrogen exceeds the concentration of phosphorus more than seven times, the lack of phosphorus will limit the development of organisms. 
The phosphorus transformation cycle is simpler in comparison with the nitrogen transformation cycle. It includes the consumption of inorganic phosphorus forms by plant organisms and subsequent decomposition or hydrolysis for transformation the dead matter back into inorganic forms.

Silicon is a part of the chemical composition of all natural waters, unlike other components, as silicon compounds are ubiquitous in rocks. The source of silicon in water are precipitation; the death of terrestrial and water plant organisms; waste water enterprises, producing the ceramic, cement, glass products, silicate paints, binders, organosilicon rubber, etc. Part of the silicon is in the dissolved condition in the form of silicic acid and polysilic acids:

$$
\mathrm{H}_{4} \mathrm{SiO}_{4} \leftrightarrow \mathrm{H}+\mathrm{H}_{3} \mathrm{SiO}_{4}^{-} .
$$

Hydrogen, oxygen, nitrogen, phosphorus, magnesium, iron, copper, manganese, zinc, molybdenum, sulfur, potassium and calcium and other elements are necessary for all seaweeds. The ratio of essential nutrients in seaweeds was determined by Redfield [10] in 1950s: the $C: N: P$ proportion is equaled to the 42:7:1 in a weight and 106:16:1 in atomic equivalents respectively. The equation of average algal composition and absorption was developed by Stumm and Morgan and has the form:

$$
106 \mathrm{CO}_{2}+16 \mathrm{NO}_{3}^{-}+\mathrm{HPO}_{4}^{-}+122 \mathrm{H}_{2} \mathrm{O}+18 \mathrm{H}^{+} \leftrightarrow\left(\mathrm{C}_{106} \mathrm{H}_{263} \mathrm{O}_{110} \mathrm{~N}_{16} \mathrm{P}_{1}+138 \mathrm{O}_{2}\right) .
$$

Conversion factors to the organic matter of silicon, nitrogen and phosphorus for natural populations of phytoplankton are determined in accordance with the ratio by Redfield as $S i: N: P=$ 23:16:1 in atomic equivalent. In the Sterner и Elser paper, the absorption of nutrients by plants and subsequent transfer of these substances to other organisms is possible in different stoichiometric ratios.

Problem statement. The model of biochemical transformation of phosphorus, nitrogen and silicon forms is based on the system of transport equations of biogenic substances, the form of which for each $F_{i}$ model block has the form [11-15]:

$$
\frac{\partial q_{i}}{\partial t}+u \frac{\partial q_{i}}{\partial x}+v \frac{\partial q_{i}}{\partial y}+w \frac{\partial q_{i}}{\partial z}=\operatorname{div}\left(k \operatorname{grad} q_{i}\right)+R_{q_{i}},
$$

where $F_{i}$ is a concentration of $i$-th component; $u, v, w$ are the components of water flow velocity vector; $u=(u, v, w), \operatorname{div}\left(k \operatorname{grad} q_{i}\right)=\frac{\partial}{\partial x}\left(k_{h} \frac{\partial q_{i}}{\partial x}\right)++\frac{\partial}{\partial y}\left(k_{h} \frac{\partial q_{i}}{\partial y}\right)+\frac{\partial}{\partial z}\left(k_{v} \frac{\partial q_{i}}{\partial z}\right) ; R_{q_{i}}$ is the chemicalbiological source, index $i$ is indicated the type of substances, $i \in M, M=\left\{F_{1}, F_{2}, F_{3}, P O_{4}, P O P, D O P\right.$, $\mathrm{NO}_{3}, \mathrm{NO}_{2}, \mathrm{NH}_{4}, \mathrm{Si}$ \} (the symbols in curly brackets are explained below).

Chemical-biological sources were described by the following equations [16-22], [23-26]:

$$
\begin{gathered}
R_{F_{i}}=C_{F_{i}}\left(1-K_{F_{i} R}\right) q_{F_{i}}-K_{F_{i} D} q_{F_{i}}-K_{F_{i} E} q_{F_{i}}, \\
R_{P O P}=\sum_{i=1}^{3} s_{P} K_{F_{i} D} q_{F_{i}}-K_{P D} q_{P O P}-K_{P N} q_{P O P}, \\
R_{D O P}=\sum_{i=1}^{3} s_{P} K_{F_{i} E} q_{F_{i}}+K_{P D} q_{P O P}-K_{D N} q_{D O P},
\end{gathered}
$$




$$
\begin{gathered}
R_{P O_{4}}=\sum_{i=1}^{3} s_{P} C_{F_{i}}\left(K_{F_{i} R}-1\right) q_{F_{i}}+K_{P N} q_{P O P}+K_{D N} q_{D O P}, \\
R_{N H_{4}}=\sum_{i=1}^{3} s_{N} C_{F_{i}}\left(K_{F_{i} R}-1\right) \frac{f_{N}^{(2)}\left(N H_{4}\right)}{f_{N}\left(N O_{3}, N O_{2}, N H_{4}\right)} q_{F_{i}}-K_{42} q_{N H_{4}}, \\
R_{N O_{2}}=\sum_{i=1}^{3} s_{N} C_{F_{i}}\left(K_{F_{i} R}-1\right) \frac{f_{N}^{(1)}\left(N O_{3}, N O_{2}\right)}{f_{N}\left(N O_{3}, N O_{2}, N H_{4}\right)} \cdot \frac{q_{N O_{2}}}{q_{N O_{2}}+q_{N O_{3}}} q_{F_{i}}+K_{42} q_{N H_{4}}-K_{23} q_{N O_{2}}, \\
R_{N O_{3}}=\sum_{i=1}^{3} s_{N} C_{F_{i}}\left(K_{F_{i} R}-1\right) \frac{f_{N}^{(1)}\left(N O_{3}, N O_{2}\right)}{f_{N}\left(N O_{3}, N O_{2}, N H_{4}\right)} \cdot \frac{q_{N O_{3}}}{q_{N O_{2}}+q_{N O_{3}}} q_{F_{i}}+K_{23} q_{N O_{2}}, \\
R_{S i}=s_{S i} K_{F_{3} D} q_{F_{3}}, i \in\{1,2,3\},
\end{gathered}
$$

where 1 is the $C h V, 2$ is the $A F-A, 3$ is the $S c, C h V, A F-A, S c$ are the symbolic definition of plankton types) $K_{F_{i} R}$ is the specific respiration rate of phytoplankton; $K_{F_{i} E}$ is the specific rate of phytoplankton dying; $K_{F_{i} E}$ is the specific rate of phytoplankton excretion; $K_{P D}$ is the specific speed of autolysis POP; $K_{P N}$ is the coefficient of potatopolice POP; $K_{D N}$ is the coefficient of potatopolice DOP; $K_{42}$ is the specific rate of ammonium oxidation to nitrites during nitrification; $K_{23}$ is the specific oxidation rate of nitrite to nitrate in the nitrification process; $s_{P}, s_{N}, s_{S i}$ are the normalization factors between the content of $\mathrm{N}, \mathrm{P}, \mathrm{Si}$ in organic matter.

The growth rate of phytoplankton is determined by the expressions:

$$
\begin{gathered}
C_{F_{1,2}}=K_{N F_{1,2}} \min \left\{f_{P}\left(P O_{4}\right), f_{N}\left(N O_{3}, N O_{2}, N H_{4}\right)\right\}, \\
C_{F_{3}}=K_{N F_{3}} \min \left\{f_{P}\left(P O_{4}\right), f_{N}\left(N O_{3}, N O_{2}, N H_{4}\right), f_{S i}(S i)\right\},
\end{gathered}
$$

where $K_{N F}$ is the maximum specific growth rate of phytoplankton.

Let us describe the dependencies of nutrient content by the following expressions:

- for phosphorus: $f_{P}\left(q_{P O_{4}}\right)=\frac{q_{P O_{4}}}{q_{P O_{4}}+K_{P O_{4}}}$, где $K_{P O_{4}}$ is the phosphates half-saturation constant;

- for silicon: $f_{S i}\left(q_{S i}\right)=\frac{q_{S i}}{q_{S i}+K_{S i}}$, где $K_{S i}$ is the silicon half-saturation constant;

- for nitrogen: $f_{N}\left(q_{N_{3}}, q_{N_{2}}, q_{N H_{4}}\right)=f_{N}^{(1)}\left(q_{N_{3}}, q_{N O_{2}}\right)+f_{N}^{(2)}\left(q_{N H_{4}}\right)=$

$$
=\frac{\left(q_{\mathrm{NO}_{3}}+q_{\mathrm{NO}_{2}}\right) \exp \left(-K_{p s i} q_{\mathrm{NH}_{4}}\right)}{K_{\mathrm{NO}_{3}}+\left(q_{\mathrm{NO}_{3}}+q_{\mathrm{NO}_{2}}\right)}+\frac{q_{\mathrm{NH}_{4}}}{K_{\mathrm{NH}_{4}}+q_{\mathrm{NH}_{4}}},
$$

where $K_{\mathrm{NO}_{3}}$ is the nitrates half-saturation constant; $K_{\mathrm{NH}_{4}}$ is the ammonium half-saturation constant; $K_{p s i}$ is the ammonia inhibition coefficient.

The velocity vector of the water flow at any time for the system (1), initial conditions $q_{i}$ are defined as:

$$
q_{i}(x, y, z, 0)=q_{i}^{0}(x, y, z),(x, y, z) \in \bar{G}, \quad i \in M
$$


Let the boundary $\Sigma$ of a cylindrical domain $G$ is the sectionally smooth; $\Sigma=\Sigma_{H} \cup \Sigma_{o} \cup \sigma$, where $\Sigma_{H}$ is the water bottom surface; $\Sigma_{o}$ the unperturbed surface of the water environment; $\sigma$ is the lateral (cylindrical) surface. Let $u_{n}$ is the normal component of the water flow velocity vector to the $\Sigma$ surface; $n$ is the outer normal vector to the $\Sigma$. Let assume the concentrations $q_{i}$ in the form:

- at the lateral boundary

$$
q_{i}=0, \text { if } u_{n}<0, i \in M ; \frac{\partial q_{i}}{\partial n}=0 \text {, if } u_{n} \geq 0, i \in M ;
$$

- at $\Sigma_{o}: \frac{\partial q_{i}}{\partial z}=\varphi_{i}, \quad i \in M$

- on the bottom:

$$
\begin{gathered}
\frac{\partial q_{i}}{\partial z}=\varepsilon_{1, i} q_{i}, i \in\left\{F_{1}, F_{2}, F_{3}\right\}, \frac{\partial q_{i}}{\partial z}=\varepsilon_{2, i} q_{i}, \\
i \in\left\{P O_{4}, P O P, D O P, N O_{3}, N O_{2}, N H_{4}, S i\right\},
\end{gathered}
$$

where $\varphi_{i}$ is the given functions; $\varepsilon_{1, i}, \varepsilon_{2, i}$ are nonnegative constants, $\varepsilon_{1, i}, i \in\left\{F_{1}, F_{2}, F_{3}\right\}$ take into account the lowering of algae to the bottom and their deposition; $\varepsilon_{2, i}, i \in\left\{\mathrm{PO}_{4}, \mathrm{POP}, \mathrm{DOP}, \mathrm{NO}_{3}, \mathrm{NO}_{2}, \mathrm{NH}_{4}, \mathrm{Si}\right\}$ take into account absorption the nutrient by bottom sediments.

Approval. Let the initial boundary value problem for the system of equations, linearized for the right side, be set as:

$$
\begin{gathered}
\frac{\partial q_{i}}{\partial t}+\operatorname{div}\left(u, q_{i}\right)=\operatorname{div}\left(k \operatorname{grad} q_{i}\right)+R_{q_{i}}^{n}\left(q_{i}\right), \\
R_{F_{i}}^{n}\left(q_{F_{i}}\right)=C_{F_{i}}^{n}\left(1-K_{F_{i} R}\right) q_{F_{i}}-K_{F_{i} D} q_{F_{i}}-K_{F_{i} E} q_{F_{i}}, i=1,2,3, \\
R_{P O P}^{n}\left(q_{P O P}\right)=\sum_{i=1}^{3} s_{P} K_{F_{i} D} q_{F_{i}}^{n}-K_{P D} q_{P O P}-K_{P N} q_{P O P}, \\
R_{D O P}^{n}\left(q_{D O P}\right)=\sum_{i=1}^{3} s_{P} K_{F_{i} E} q_{F_{i}}^{n}+K_{P D} q_{P O P}^{n}-K_{D N} q_{D O P}, \\
R_{P O_{4}}^{n}\left(q_{P O_{4}}\right)=\sum_{i=1}^{3} s_{P} C_{F_{i}}^{n}\left(K_{F_{i} R}-1\right) q_{F_{i}}^{n}+K_{P N} q_{P O P}^{n}+K_{D N} q_{D O P}^{n}, \\
\sum_{i=1}^{3} \frac{s_{N} C_{F_{i}}^{n}\left(K_{F_{i} R}-1\right) q_{F_{i}}^{n}}{\left(K_{N H_{4}}+q_{N H_{4}}^{n}\right)\left(q_{N O_{3}}^{n}+q_{N O_{2}}^{n}\right) \exp \left(-K_{p s i} q_{N H_{4}}^{n}\right)}+q_{N H_{4}}^{n}-K_{42} q_{N H_{4}}, \\
K_{N O_{3}}+\left(q_{N O_{3}}^{n}+q_{N O_{2}}^{n}\right) \\
R_{N O_{3}}^{n}\left(q_{F_{i} O_{3}}^{n}\left(K_{F_{i} R}-1\right) \exp \left(-K_{p s i} q_{N H_{4}}^{n}\right) q_{F_{i}}^{n}\right. \\
\sum_{i=1}^{3} \frac{q_{N H_{4}}^{n}\left(K_{N O_{3}}+q_{N O_{3}}^{n}+q_{N O_{2}}^{n}\right)}{K_{N H_{4}}+q_{N H_{4}}^{n}} \cdot q_{N O_{3}}
\end{gathered}
$$




$$
\begin{gathered}
R_{\mathrm{NO}_{2}}^{n}\left(q_{\mathrm{NO}_{2}}\right)=\sum_{i=1}^{3} \frac{s_{N} C_{F_{i}}^{n}\left(K_{F_{i} R}-1\right) \exp \left(-K_{p s i} q_{N H_{4}}^{n}\right) q_{F_{i}}^{n}}{\left(q_{\mathrm{NO}_{3}}^{n}+q_{\mathrm{NO}_{2}}^{n}\right) \exp \left(-K_{p s i} q_{N H_{4}}^{n}\right)+\frac{q_{N H_{4}}^{n}\left(K_{\mathrm{NO}_{3}}+q_{N O_{3}}^{n}+q_{N O_{2}}^{n}\right)}{K_{N_{4}}+q_{N H_{4}}^{n}}} \cdot q_{\mathrm{NO}_{2}}+ \\
+K_{42} q_{\mathrm{NH}_{4}}^{n}-K_{23} q_{\mathrm{NO}_{2}}, R_{S i}^{n}\left(q_{S i}\right)=s_{S_{i}} K_{\mathrm{F}_{3} \mathrm{D}} q_{F_{3}}^{n}
\end{gathered}
$$

with appropriate initial and boundary conditions. Let $q_{i}$ belong to the class $C^{2}(G) \cap C^{1}(\bar{G}) \cap C^{1}(0<t \leq T), k_{h}(z), k_{v}(z) \in C^{1}(\bar{G}), R_{q_{i}}(x, y, z) \in C^{1}(\bar{G})$; and inequalities are executed for each $n=\overline{0, N-1}$ :

$$
\begin{gathered}
\frac{4 k_{h}}{H_{x}^{2}}+\frac{4 k_{h}}{H_{y}^{2}}+\frac{4 k_{v}}{H_{z}^{2}}+K_{F_{1} D}+K_{F_{1} E}>K_{N F_{1}} \min \left\{f_{P}^{n}\left(P O_{4}\right), f_{N}^{n}\left(N O_{3}, N O_{2}, N H_{4}\right)\right\}\left(1-K_{F_{1} R}\right) \\
\frac{4 k_{h}}{H_{x}^{2}}+\frac{4 k_{h}}{H_{y}^{2}}+\frac{4 k_{v}}{H_{z}^{2}}+K_{F_{2} D}+K_{F_{2} E}>K_{N F_{2}} \min \left\{f_{P}^{n}\left(P O_{4}\right), f_{N}^{n}\left(N O_{3}, N O_{2}, N H_{4}\right)\right\}\left(1-K_{F_{2} R}\right) \\
\frac{4 k_{h}}{H_{x}^{2}}+\frac{4 k_{h}}{H_{y}^{2}}+\frac{4 k_{v}}{H_{z}^{2}}+K_{F_{3} D}+K_{F_{3} E}> \\
>K_{N F_{3}} \min \left\{f_{P}^{n}\left(P O_{4}\right), f_{N}^{n}\left(N O_{3}, N O_{2}, N H_{4}\right), f_{S i}^{n}(S i)\right\}\left(1-K_{F_{3} R}\right) \\
\frac{4 k_{h}}{H_{x}^{2}}+\frac{4 k_{h}}{H_{y}^{2}}+\frac{4 k_{v}}{H_{z}^{2}}+K_{42}>\sum_{i=1}^{3} \frac{s_{N} C_{F_{i}}^{n}\left(K_{F_{i} R}-1\right) q_{F_{i}}^{n}}{\frac{\left.K_{N H_{4}}+q_{N H_{4}}^{n}\right)\left(q_{N O_{3}}^{n}+q_{N O_{2}}^{n}\right) \exp \left(-K_{p s i} q_{N H_{4}}^{n}\right)}{K_{N O_{3}}+\left(q_{N O_{3}}^{n}+q_{N O_{2}}^{n}\right)}+q_{N H_{4}}^{n}} \\
\frac{4 k_{h}}{H_{x}^{2}}+\frac{4 k_{h}}{H_{y}^{2}}+\frac{4 k_{v}}{H_{z}^{2}}>\sum_{i=1}^{3} \frac{s_{F_{i}}^{n}\left(K_{F_{i} R}-1\right) \exp \left(-K_{p s i} q_{N H_{4}}^{n}\right) q_{F_{i}}^{n}}{\left(q_{N O_{3}}^{n}+q_{N O_{2}}^{n}\right) \exp \left(-K_{p s i} q_{N H_{4}}^{n}\right)+\frac{q_{N H_{4}}^{n}\left(K_{N O_{3}}+q_{N O_{3}}^{n}+q_{N O_{2}}^{n}\right)}{K_{N H_{4}}+q_{N H_{4}}^{n}}}
\end{gathered}
$$

So, the solution of the considered problem exists only.

Conclusion. The stoichiometric ratios of nutrients for phytoplankton algae were considered on the basis of which a limiting substance can be determined. Observational models describing the consumption, accumulation of nutrients by phytoplankton and the growth rate of phytoplankton are considered. Three-dimensional mathematical transformation model of phosphorus, nitrogen and silicon forms in the problem of phytoplankton dynamics for shallow waters is developed and researched. It takes into account the convective and diffusive transports; absorption and isolation of nutrients by phytoplankton; transformation cycles of phosphorus, nitrogen and silicon forms. The analytical researching of the constructed continuous model was performed; the inequalities that guarantee the existence and uniqueness of the problem were determined.

\section{References}

1. Van Straten G., Keesman K.J. Uncertainty propagation and speculation in projective forecasts of environmental change: a lake eutrophication example // Journal of Forecasting. - 1991. - №10. - pp. 163-190. 
2. Park R.A. A generalized model for simulating lake ecosystems // Simulation. - 1974. №23 (2). - pp. 33-50.

3. Bierman V.J., Verhoff F.H., Poulson T.C., Tenney M.W. Multinutrient dynamic models of algal growth and species competition in eutrophic lakes // Modeling the eutrophication process. - Ann Arbor: Ann Arbor Science, 1974.

4. Chen C.W. Concepts and utilities of ecologic models // Journal of Sanitary Engineering Division, ASCE. - 1970. - No.96 (5). - pp. 1085-1097.

5. Jorgensen S.E. An eutrophication model for a lake // Ecological Modelling. - 1976. No.2(2). - Pp. 147-165.

6. Jorgensen S.E., Mejer H., Friis M. Examination of a lake model // Ecological Modelling. - 1978. - No.4 (2-3). - pp. 253-278.

7. Brodskii A. K. A short course on General ecology: a textbook for Universities. - St. Petersburg: Dean, 2000. - 224 p.

8. Williams B.J. Hydrobiological modelling. - University of Newcastle, NSW, Australia: www.lulu.com, 2006. -680 p.

9. Epply R.W., Rogers J.N., McCarthy J.J. Half-saturation constants for uptake of nitrate and ammonium by marine phytoplankton // limnology and Oceanography. - 1969. - No.14. - pp. 912920.

10. Redfield A.C. The biological control of chemical factors in the environment // American Scientist. - 1958, №46. - pp. 205-222.

11. Samarskii A.A., Vabischevich P. N. Numerical methods for solving convection-diffusion problems. - M.: Edditorial URSS, 1999.

12. Goloviznin V. M., Samara A. A. Difference approximation of convective transport with spatial splitting of time derivative // Mathematical Models and Computer Simulations. - 1998. - Vol. 10, No.1. - pp. 86-100.

13. Sukhinov A.I., Chistyakov A.E., Iakobovski M.V. Accuracy of the numerical solution of diffusion-convection equation based on difference schemes of second and fourth orders of approximation order // Vestn. SUSU. Ser. Calc. mod. inform. - 2016. - Vol. 5, No.1. - pp. 47-62.

14. Sukhinov A.I., Belov Yu.V. Mathematical model of transformation of the phosphorus, nitrogen and silicon forms in a moving turbulent water environment in problems of plankton populations dynamics // Engineering journal of Don. - 2015. - Vol. 37, No.3. - pp. 50.

15. Sukhinov A.I., Khachunts D.S., Chistyakov A.E. A mathematical model of pollutant propagation in near-ground atmospheric layer of a coastal region and its software implementation // Computational Mathematics and Mathematical Physics. - 2015. - Vol. 55, No.7. - pp. 1216-1231.

16. Sukhinov A.I., Nikitina A.V., Chistyakov A.E. Modeling of biological rehabilitation scenario of the Azov Sea // Mathematical modeling. - 2012. - Vol. 24, No.9. - pp. 3-21.

17. Nikitina A.V., Sukhinov A.I., Ugolnitsky, G.A., Usov A.B., Chistyakov A.E., Puchkin M.V., Semenov I.S. Optimal management of sustainable development with biological rehabilitation of the Azov Sea // Mathematical modeling. - 2016. - Vol. 28, No.7. - pp. 96-106.

18. Nikitina A.V., Puchkin M.V., Semenov I.S., Sukhinov A.I., Ugolnitsky G.A., Usov A.B., Chistyakov A.E. Differential-game model of zamora prevention in shallow waters // Managing large systems. - 2015. - Issue 55. - pp. 343-361.

19. Trân J.K. A predator-prey functional response incorporating indirect interference and depletion // Verh. Internat. Verein. Limnol. - 2008. - Vol. 30, Pt 2. - pp. 302-305.

20. Petrov Igor B. Application of grid-characteristic method for numerical solution of deformable solid mechanics dynamical problems // Computational Mathematics and Information Technologies. - 2017. Vol. 1, No 1. - pp. 1-20. 
21. Sukhinov A.I., Sidoryakina V.V., Sukhinov A.A. Sufficient convergence conditions for positive solutions of linearized two-dimensional sediment transport problem // Computational Mathematics and Information Technologies. - 2017. Vol. 1, No 1. - pp. 21-35.

22. Nikitina A.V., Semenyakina A.A. Mathematical modeling of eutrophication processes in Azov Sea on supercomputers // Computational Mathematics and Information Technologies. - 2017. Vol.1, No 1. - pp. 82-101.

23. Chistyakov A.E., Protsenko E.A., Timofeeva E.F. Mathematical modeling of oscillatory processes with a free boundary // Computational Mathematics and Information Technologies. - 2017. Vol.1, No 1. - pp. 102-112.

24. Tyutyunov Yu., Senina I., Arditi R. Clustering due to acceleration in the response to population gradient: a simple self-organization model // The American Naturalist. - 2004, 164. - pp. 722-735.

25. Volterra V. Variations and fluctuations of the number of individuals in animal species living together // Rapp. P. - V. Reun. Cons. Int. Explor. Mer. - 1928. 3, pp. 3-51.

26. Yakushev E.V., Mikhailovsky G.E. Mathematical modeling of the influence of marine biota on the carbon dioxide ocean-atmosphere exchange in high latitudes // Air-Water Gas Transfer, Sel. Papers, Third Int. Symp., Heidelberg University, ed. by B. Jaehne and E.C. Monahan, AEON Verlag \& Studio, Hanau. - 1995. - pp. 37-48.

\section{Authors:}

Semenyakina Alona Aleksandrovna, Supercomputers and Neurocomputers Research Center, Co Ltd. (Italyansky lane, 106, Taganrog, Russian Federation), Candidate of Technical Science, Researcher

Sumbaev Vladimir Valeryevich, Southern Federal University (Nekrasovsky lane, 44, Taganrog, Russian Federation), graduate student

Protsenko Sofya Vladinirovna, Don State Technical University (1st Gagarin Square, Rostov-onDon, Russian Federation), postgraduate student 
Разработка модели транспорта и трансформации соединений азота, фосфора и кремния в мелководном водоеме *

\section{А.А. Семенякина ${ }^{* *}$, В.В.Сумбаев ${ }^{* * *}$, С. В. Проценко*** \\ Донской государственный технический университет, Ростов-на-Дону, Российская Федерация Южный федеральный университет, Таганрог, Российская Федерация}

Научно-исследовательский центр супер-ЭВМ и нейрокомпьютеров, Таганрог, Российская Федерация

В работе приведены стехиометрические соотношения питательных биогенных веществ вещество. Рассмотрены модели наблюдений, описывающие потребление, накопление фитопланктоном питательных веществ и скорость роста фитопланктона. Построена и исследована трехмерная математическая модель трансформации форм фосфора, азота и кремния в задаче динамики фитопланктона для мелководных водоемов, учитывающая конвективный и диффузионный переносы, поглощение и выделение питательных веществ фитопланктоном, циклы превращений форм фосфора, азота и кремния.

Ключевые слова: математическая модель; трансформация; биогенные вещества; фитопланктон; стехиометрические соотношения; биогеохимический цикл

\section{Авторы:}

Семенякина Алёна Александровна, Научно-исследовательский центр супер-ЭВМ и нейрокомпьютеров (347900, Россия, Ростовская область, г. Таганрог, пер. Итальянский, дом 106), кандидат технических наук, научный сотрудник

Сумбаев Владимир Валерьевич, Южный Федеральный Университет (347928, Россия, Ростовская область, г. Таганрог, пер. Некрасовский, 44), аспирант

Проценко Софья Владимировна, Донской государственный технический университет (344000 Ростов-на-Дону, пл. Гагарина, д. 1), аспирант

\footnotetext{
* Работа выполнена по теме № 2.6905.2017/БЧ в рамках выполнения госзадания Минобрнауки России в части НИР.

** E-mail: j.a.s.s.y@mail.ru, valdec4813@mail.ru.

*** E-mail: rab55555@ rambler.ru.
} 